\title{
Traditional play therapy "Bancakan" efektif dalam mengurangi kejenuhan pembelajaran daring siswa SMA saat pandemi Covid-19
}

\author{
Fatur Rahman Al Isfahani $\left.1^{*}\right)$, Sutijono², \& Dimas Ardika Miftah Farid ${ }^{3}$ \\ Universitas PGRI Adi Buana Surabaya ${ }^{123}$
}

*) Alamat korespondensi: JI. Dukuh Menanggal XII, Surabaya, 60234, Indonesia; E-mail: kipank@gmail.com

Article History:

Received: 22/03/2021;

Revised: 21/06/2021;

Accepted: 21/06/2021;

Published: 30/06/2021.

How to cite: Isfahani, F.R.A., Sutijono, \& Farid, D.A.M. (2021). Traditional play therapy "Bancakan" efektif dalam mengurangi kejenuhan pembelajaran daring siswa SMA saat pandemi Covid-19. Teraputik: Jurnal Bimbingan dan Konseling, 5(1), pp. 77-86. DOI: 10.26539/teraputik.51604

\begin{abstract}
Abstrak: Penelitian betujuan untuk mengetahui pengaruh play therapy dengan permainan tradisional "Bancakan" dalam bimbingan kelompok terhadap kejenuhan pembelajaran online pada saat pandemi covid-19 bagi siswa di SMA Negeri 1 Sangkapura. Metode eksperimen yang diterapkan adalah desain one group pre-test-post-test yaitu metode rujukan pada penelitian ini. Subyek penelitian berjumlah delapan siswa kelas XI yang mengalami kejenuhan belajar dengan kategori tinggi. Pengujian hipotesis yang digunakan oleh peneliti yaitu Wilcoxon signed ranks test. Hasil penelitian menunjukkan bahwa terdapat perbedaan yang signifikan terhadap kejenuhan pembelajaran bagi siswa antara pre-test dan post-test dimana kejenuhan belajar pada post-test lebih rendah dari pre-test yang artinya play therapy dengan permainan tradisional "Bancakan" dalam bimbingan kelompok berpengaruh terhadap kejenuhan belajar (Asymp. Sig. $=0,012$ perbandingan Asymp. Sig. $=0.012<\alpha=0,05$ ). Berdasarkan penelitian ini, bisa dapat disimpulkan bahwa play therapy dengan permainan tradisional "Bancakan" dalam bimbingan kelompok memiliki pengaruh terhadap kejenuhan pembelajaran bagi siswa di SMA Negeri 1 Sangkapura.
\end{abstract}

Kata Kunci: Terapi Bermain Bancakan, Kejenuhan Belajar

Abstract: The purpose of this study was to determine the effect of play therapy with the traditional game "Bancakan" in group guidance on students' online learning boredom during the Covid-19 pandemic at SMA Negeri 1 Sangkapura. The experimental method with the one group pretest-posttest design is the reference method in this study. Researchers selected 8 student subjects from class XI who experienced high category learning burnout. Hypothesis testing used by researchers is the Wilcoxon signed ranks test. The results of the research conducted by the researcher showed that there was a significant difference in learning burnout between pre-test and post-test where learning burnout on the post-test was lower than the pre-test, which means that play therapy with the traditional game "Bancakan" in-group guidance. effect on learning boredom (Asymp. Sig. $=0.012$ comparison of Asymp. Sig. $=0.012$ $<0.05$ ). Based on this research, it can be said that play therapy with the traditional game "Bancakan" in-group guidance has an effect on student learning burnout at SMA Negeri 1 Sangkapura.

Keywords: Traditional Play Therapy Bancakan, Learning Saturation

\section{Pendahuluan}

Permulaan tahun 2020 silam, dikejutkannya dunia dengan ramainya virus yang melanda yaitu coronavirus jenis baru atau SARS-CoV-2, yang banyak orang ketahuinya Namanya yaitu Coronavirus disease 2019 atau COVID-19. Wuhan merupakan kota yang ada di China yang mengawali munculnya COVID-19 ini, tepatnya diakhir Desember 2019 lalu. COVID-19 merupakan bencana yang melanda seluruh masyarakat dunia. Banyak sekali aktivitas-aktivitas dari kehidupan bermasyarakat yang terganggu, salah satunya pendidikan. Hampir seluruh negara yagn ada di dunia membuat kebijakan untuk meliburkan kegiatan sekolah dimulai dari TK sampai dengan Pendidikan setara perguruan tinggi, Indonesia juga termasuk negara yang meliburkan kegiatan sekolah. Salah satu faktor yang muncul akibat pandemi covid-19 adalah pembelajaran dilaksanakan secara daring. Pembelajaran secara daring merupakan hal yang 
78 Traditional play therapy "Bancakan" efektif dalam mengurangi kejenuhan pembelajaran daring siswa SMA saat pandemi Covid-19

menggemparkan baik bagi siswa maupun orang tua, di mana biasanya mereka menjalankan kegiatan yang ada di luar rumah. Hal ini juga bisa menyebabkan masalah pada psikologis anakanak yang biasanya mereka belajar secara tatap muka dengan guru dan memiliki kehidupan sosial dengan teman-teman, sehinga, sekarang harus menjalankan kegiatan yang biasanya dilakukan di luar menjadi hanya di rumah saja atau secara online. Diketahui bahwasannya proses dalam pelaksanaannya belum bisa untuk diukur dan diuji dikarenakan fenomena dunia seperti ini belum pernah dialami di masa sebelumnya.

Bagi siswa, rasa jenuh dalam belajar dalam jaringan dapat dirasakan dikarenakan terlalu konstan atau tetap, kurangnya variasi kalimat, dan tidak mampu melakukan interaksi secara langsung atau tatap muka dengan teman-teman dan guru. Kesepian juga dirasakan sebagai pengaruh terhadap kejenuhan pembelajaran (Pawicara dan Conilie, 2020). Di sisi lain, sistem belajar dirasa yang kurang efektif, sehingga mengakibatkan siswa yang kurang memahami materi yang diberikan (Vitasari, 2016). Kejenuhan belajar adalah sebuah keadaan mental seseorang saat merasakan lelah dan bosan yang terlalu, sehingga memunculkan perasaan lesu tanpa semangat atau hilangnya gairah untuk hidup dalam melakukan aktivitas belajar. Kejenuhan yang disebabkan oleh belajar terjadi dkarenakan adanya dorongan bagi siswa untuk selalu menaati peraturan tugas-tugas yang diberikan guru bagi siswanya. Kejenuhan yang disebabkan oleh belajar juga dialami dikarenakan adanya aktivitas yang selalu stagnan yang dikerjakan oleh siswa pada setiap harinya. Kejenuhan yang disebabkan oleh belajar ini akan dangat mempunyai dampak atau pengaruh yang sangat besar bagi siswa untuk berlangsungnya pembelajaran. Perilaku yang ditunjukkan seseorang yang mengalami kejenuhan itu mudah marah dan mudah putus asa (Hidayat, 2016).

Dari fenomena yang terjadi di SMA Negeri 1 Sangkapura, pembelajaran dalam jaringan memiliki pengaruh yang sangat besar terhadap kejenuhan pembelajaran siswa dikarenakan cara belajar yang berbeda. terdapat kemungkinan besar siswa merasa jenuh saat mengikuti pembelajaran dalam jaringan yang telah ditentukan oleh pihak sekolah, dikarenakan keinginan untuk bermain. Siswa SMA Negeri 1 Sangkapura memiliki perasaan bosan akibat tidak bisa berjumpa dengan teman-teman serta guru, sehingga hanya mampu bertemu secara online melalui media virtual, biasanya pengimplementasiannya dilakukan menggunakan google meeting, sehingga siswa mengalami jenuh dalam belajarnya yang mengakibatkan prestasinya menurun.

Penelitian ini menggunakan layanan bimbingan kelompok. Layanan bimbingan kelompok ialah suatu bimbingan yang diimplementasikan pada kondisi kelompok. Menurut Nurihsan (2006) "bimbingan kelompok ialah proses pemberian kemudahan kepada konseli oleh konselor yang dilakukan dalam keadaan kelompok". Sedangkan menurut Yusuf (2006) bimbingan kelompok merupakan bantuan yang diberikan kepada konseli pada saat kondisi kelompok. Kasus yang diangkat pada bimbingan kelompok ialah kasus yang dirasakan secara bersama-sama dan tanpa rahasia, baik itu masalah pribadi, sosial, belajar, maupun karir.

Jadi dapat dikatakan bahwasannya layanan bimbingan kelompok merupakan suatu aktivitas yang dikerjakan oleh seorang konselor terhadap konseli dengan menerapkan dinamika kelompok yaitu dengan melakukan interaksi saling memberikan saran, menyatakan pendapa dan lainnya, yang mana konselor sebagai penyedia informasi-informasi yang akan berguna dalam memberikan bantuan kepada konseli sebagai anggota kelompok untuk mencapai perkembangan yang diinginkan baik didalam hal pribadi, sosial, belajar, dan karir.

Menurut hasil penelitian Dewi, Yosef, dan Harlina (2017: 23) kejenuhan dalam pembelajaran bagi siswa kelas XI SMK Negeri 1 Indralaya Utara digolongkan pada kategori sedang. Kejenuhan dalam pembelajaran bagi siswa kelas XI SMK Negeri 1 Indralaya Utara mendapatkan nilai mean 92 yang berada pada posisi interval 77,33 $\leq X<107,01$ dengan persentase $68,1 \%$. Kejenuhan yang terdapat di kategori sedang ini membuktikan bahwa secara umum siswa kelas XI SMK Negeri 1 Indralaya utara mengalami kejenuhan dalam kategori tinggi. Dari pengamatan yang dilakukan selama PPL oleh Dewi, Yosef, dan Harlina (2017: 23) di SMK Negeri 1 Indralaya Utara kejenuhan yang terjadi pada siswa ini diakibatkan oleh beragam aspek antara lain yaitu metode pembelajaran yang kurang menarik, dan belum cukup adanya kedekatan antara guru dan murid. 
Penelitian ini menggunakan play therapy. Play therapy merupakan suatu proses terapi yang memanfaatkan penggunaan sebuah permainan yang dijadikan media terapi supaya memberikan kemudahan untuk melihat ekspresi natural dari seorang anak yang tidak dapat diekspresikan dalam bahasa verbal dikarenakan permainan adalah jalur masuk ke dalam dunia anak (Hatiningsih, 2013).

Penelitian ini menggunakan permainan tradisional bancakan. Permainan bancakan menurut Kurniati (2016: 64) adalah sebuah permainan dengan melakukan penyusunan pecahan genting atau keramik yang tersusun sedemikian rupa, kemudian menyerupai pyramid pada prosesnya. Tugas ucing yaitu menjaga agar piramid yang telah tersusun tersebut tetap bisa berdiri dengan kukuh. Sedangkan tugas pemain lainnya yaitu melakukan hal yang berkebalikan dengan bersembunyi dari pandangan ucing dan menghancurkan susunan piramid.

Berdasarkan pemaparan di atas maka perilaku kejenuhan belajar dikalangan siswa masih sangat tinggi dan harus segera diselesaikan, sehingga muncul ketertarikan peneliti untuk melakukan penelitian tentang pengaruh play therapy dengan permainan tradisional "bancakan" dalam bimbingan kelompok terhadap kejenuhan belajar daring siswa pada saat adanya pandemi covid-19 di SMA Negeri 1 Sangkapura.

\section{Metode}

Menurut Margono, (2010: 100) rancangan penelitian merupakan dasar aktivitas peneliti untuk menyelesaikan permasalahan. Penyusunannya dilakukan secara matang, dengan demikian nantinya akan mampu untuk dimanfaatkan dan menjadi bantuan bagi peneliti maupun orang sebagai pembaca hasil penenelitian ini. Jenis penelitian dengan menggunakan preeksprimental dalam bentuk one group pre-test-postest. Subyek dilakukan pengamatan sebanyak dua kali (pre-test dan post-test) yang mana pre-test sebelum dilakukan treatment dan post-test setelah dilakukan treatment. Hasil dari pre-test dan post-test didapatkan melalui dilakukannya analisis menggunakan uji $\mathrm{T}$, berikut rancangan penelitian:

Tabel 1. Rancangan Penelitian One Group Pre-Test Post-Test Design

Sumber: Suryabrata (2014) $\mathrm{T}_{1}$
Keterangan:

\section{Hasil dan Diskusi}

Hasil

Data didapatkan setelah melakukan pre-test yang diberikan kepada 30 siswa, dimana menggunakan 8 siswa sebagai sampel penelitian yang memiliki kejenuhan belajar yang tinggi. Rincian tersebut akan diuraikan lebih rinci pada tabel 2 di bawah ini. 
80 Traditional play therapy "Bancakan" efektif dalam mengurangi kejenuhan pembelajaran daring siswa SMA saat pandemi Covid-19

Tabel 2. Rincian Sampel Menurut Pre-test

\begin{tabular}{cccc} 
No & Nama Siswa & Skor Total & Kategori \\
\hline 1. & F5 & 91 & Tinggi \\
\hline 2. & F7 & 78 & Sedang \\
\hline 3. & F13 & 89 & Tinggi \\
\hline 4. & F22 & 91 & Tinggi \\
\hline 5. & F23 & 78 & Sedang \\
\hline 6. & F25 & 84 & Tinggi \\
\hline 7. & F26 & 92 & Tinggi \\
\hline 8. & F30 & 92 & Tinggi \\
\hline
\end{tabular}

Menurut tabel di atas, hasil dari diagram data pre-test diatas menunjukan bahwa adanya 8 subjek penelitian yang mengalami peningkatan dalam kejenuhan belajar siswa pada saat sebelum adanya layanan bimbingan kelompok dengan diberikan permainan tradisional bancakan tersebut menunjukkan awal sebelum mendapat treatment.

Setelah adanya treatment yang diberikan pada 8 subjek berupa bimbingan kelompok teknik play therapy dengan adanya permainan tradisional bancakan, disajikan dalam tabel.

Tabel 3. Rincian Sampel Menurut Post-test

\begin{tabular}{cccc}
\hline No & Nama Siswa & Skor Total & Kategori \\
\hline 1. & F5 & 67 & Rendah \\
\hline 2. & F7 & 69 & Rendah \\
\hline 3. & F13 & 62 & Rendah \\
\hline 4. & F22 & 72 & Sedang \\
\hline 5. & F23 & 70 & Rendah \\
\hline 6. & F25 & 75 & Sedang \\
\hline 7. & F26 & 73 & Sedang \\
\hline 8. & F30 & 68 & Rendah \\
\hline
\end{tabular}

Pada tabel 2 dan tabel 3 dinyatakan bahwasannya tingkat kejenuhan pembelajaran masuk dalam kategori tinggi ketika pre-test rata-rata mencapai 92\%. Ketika subjek diberikan perlakuan (post-test), maka hasilnya menjadi $62 \%$ dengan rata-rata penurunan $27 \%$. Berdasarkan data tersebut, maka kejenuhan belajar siswa SMA Negeri 1 Sangkapura mengalami penurunan/reduksi ketika diberikan perlakuan bimbingan kelompok.

Untuk mengetahui apakah analisis data terhadap bimbingan kelompok teknik play therapy dengan permainan tardisional bancakan mampu mengurangi kejenuhan pembelajaran bagi siswa di SMA Negeri 1 Sangkapura dengan melalui Hasil Uji Wilcoxon dapat diketahui bahwa nilai Uji Wilcoxon atau $F=1,764$ pada taraf sifnifikansi 0,001 . Sig (2-tailed) yang bernilai 0.001 dimana $0,001<0,05$ (taraf signifikansi) maka dapat dikatakan bahwa Ha diterima dan Ho ditolak yang artinya adanya perbedaan antara Pre-Test dan Post-Test teknik play therapy dengan permainan tradisional bancakan dalam bimbingan kelompok terhadap kejenuhan pembelajaran daring siswa pada saat masa pandemi Covid-19 di SMA Negeri 1 Sangkapura.

Untuk memperkuat perubahan yang ada pada tabel 2 dan 3, dan mengetahui perubahan skor dan signifikansinya, maka peneliti menggunakan SPSS for windows versi 25 sebagai bantuan untuk mengetahui hasil dari uji Wilcoxon, berikut adalah tabel uji Wilcoxon. 
Tabel 4. Ranks

\begin{tabular}{|c|c|c|c|c|}
\hline 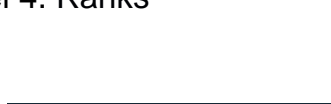 & & $\mathrm{N}$ & $\begin{array}{l}\text { Mean } \\
\text { Rank }\end{array}$ & $\begin{array}{l}\text { Sum } \\
\text { Ranks }\end{array}$ \\
\hline \multirow[t]{5}{*}{ Post test - Pre Test } & Negative & 8 & 4.5 & 36.00 \\
\hline & Ranks & a & 0 & \\
\hline & Positive Ranks & $\begin{array}{l}0 \\
b\end{array}$ & .00 & .00 \\
\hline & Ties & $\begin{array}{l}0 \\
\mathrm{c}\end{array}$ & & \\
\hline & Total & 8 & & \\
\hline
\end{tabular}

a. Post test $<$ Pre Test

b. Post test $>$ Pre Test

c. Post test $=$ Pre Test

Test Statisticsa

Post test - Pre Test

\begin{tabular}{lc}
\hline$Z$ & $-2.521^{\mathrm{b}}$ \\
\hline Asymp. Sig. (2-tailed) & .012 \\
\hline
\end{tabular}

a. Wilcoxon Signed Ranks Test

b. Based on positive ranks.

\section{Pembahasan}

Perubahan yang terjadi pada kedelapan responden tersebut disebabkan oleh beberapa faktor yang melatar belakangi masing-masing responden tidak sama setiap kondisi yang dialami. Hal ini di antaranya akan diuraikan sebagai berikut.

1. Responden F5

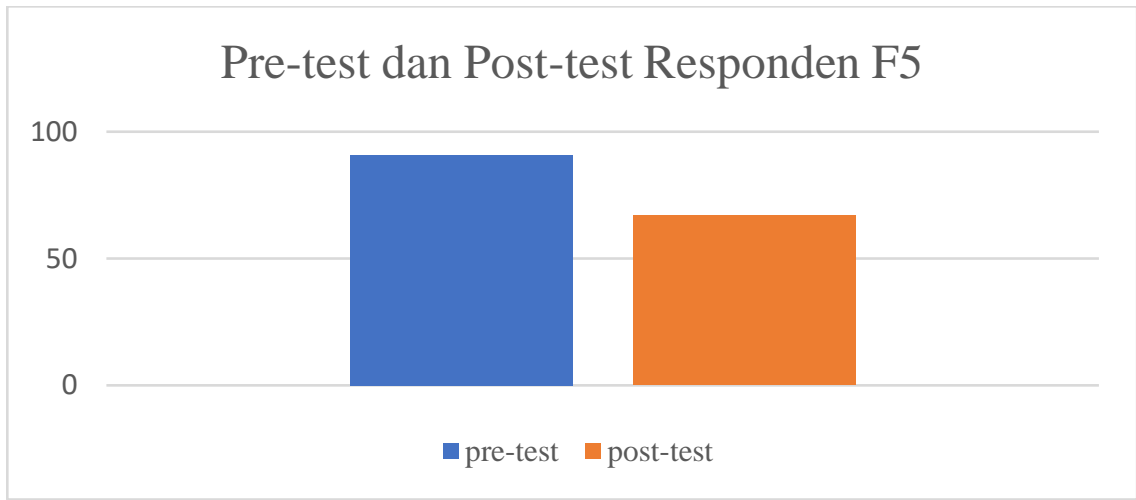

Gambar 1. Hasil dari Pre-Test dan Post-Test Responden F5

Hasil dari pre-test responden F5 mendapatkan 91 dalam kejenuhan belajar pada taraf yang tinggi. Setelah mendapatkan treatment berubah menjadi kategori kejenuhan belajar yang dialami siswa rendah dengan hasil persentase post-test sebesar 67 dan mengalami penurunan ketaraf yang lebih rendah. Sebelum mendapatkan treatment, responden tidak mau belajar sama sekali, dikarekan sekarang belajarnya di rumah sendiri tidak bertemu dengan teman-teman dikelasnya dan membuatnya merasa bosan. Namun, setelah dilakukan bimbingan kelompok play therapy dengan permainan tradisional responden tersebut dapat belajar dengan giat dan tidak merasakan bosan. 
82 Traditional play therapy "Bancakan" efektif dalam mengurangi kejenuhan pembelajaran daring siswa SMA saat pandemi Covid-19

\section{Responden F7}

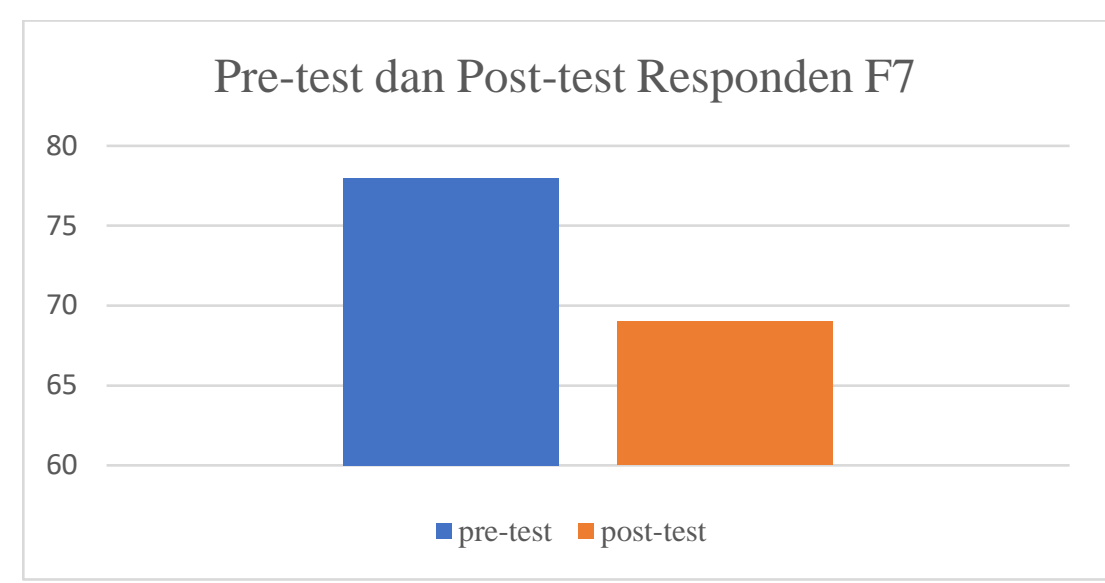

Gambar 2. Hasil dari Pre-test dan Post-test Responden F7

Skor kejenuhan belajar yang dicapai oleh responden F7. Hasil Pre-test responden F7 mendapatkan persentase sebesar 78 dalam kategori kejenuhan belajar pada taraf tinggi, dan setelah mendapatkan treatment maka skor kejenuhan belajar sebesar 69 dengan kreteria kejenuhan yang rendah. Sebelum dilakukan treatment, responden F7 sangat malas untuk belajar dengan alasan banyak sekali tugas yang didapatkan, materi yang diterima kurang jelas dan juga sulit untuk dipahami, sehingga membuatnya jenuh. Namun, setelah bimbingan kelompok play therapy dengan permainan tradisional responden mengalami perubahan, tidak malas lagi untuk belajar dan apabila ada materi yang susah dipahami bisa bertanya kepada teman kelasnya.

\section{Responden F13}

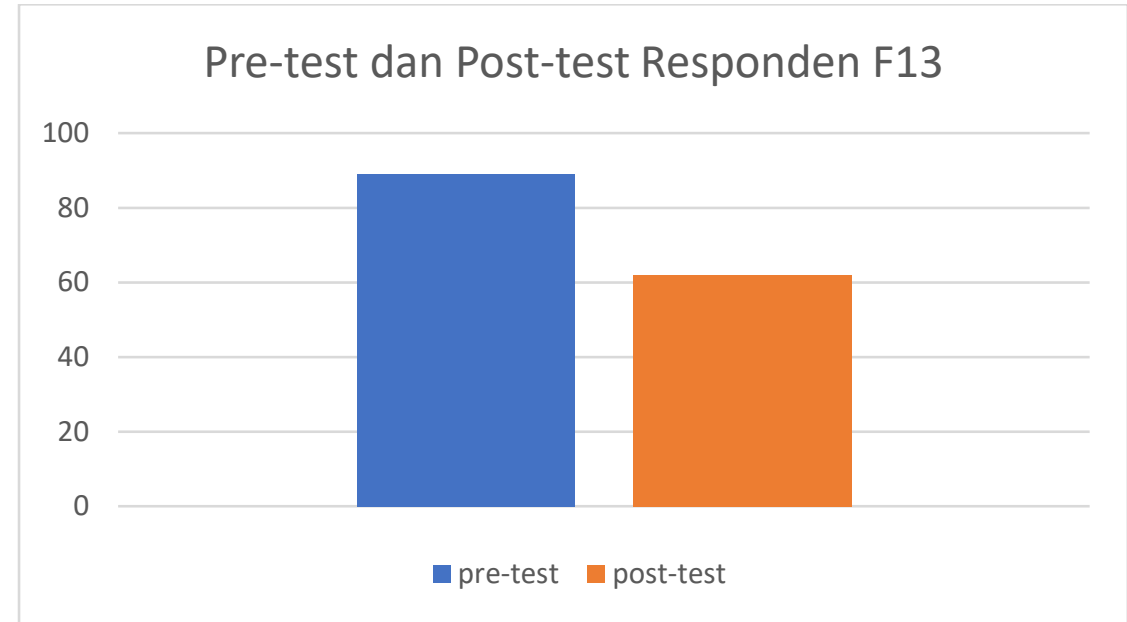

Gambar 3. Hasil dari Pre-test dan Post-test Responden F13

Skor tingkat kejenuhan belajar siswa yang dicapai oleh responden F13 meningkat. Kondisi kejenuhan belajar yang dihadapi oleh F13 sudah dalam kategori tinggi. Sebelum mendapatkan treatment skor yang dicapai sebesar 89 dan setelah mendapatkan treatment, maka skor kejenuhan belajar pada F13 menurun sebesar 62. Sebelum melakukan treatment F13 selalu merasa jenuh saat mengerjakan tugas yang didapat dari sekolah dikarenakan saat adanya covid19 tugas yang diterima siswa terlalu banyak, berbeda dengan sebelum adanya covid-19 tugas yang diterima tidak terlalu banyak dan pada saat menerima materi dari guru bisa langsung tatap muka dan mudah dipahami. Sedangkan setelah diberikan treatment maka responden merasa tenang dalam menghadapi banyaknya tugas yang didapat dan bisa menyelesaikan dengan tepat waktu. 


\section{Responden F22}

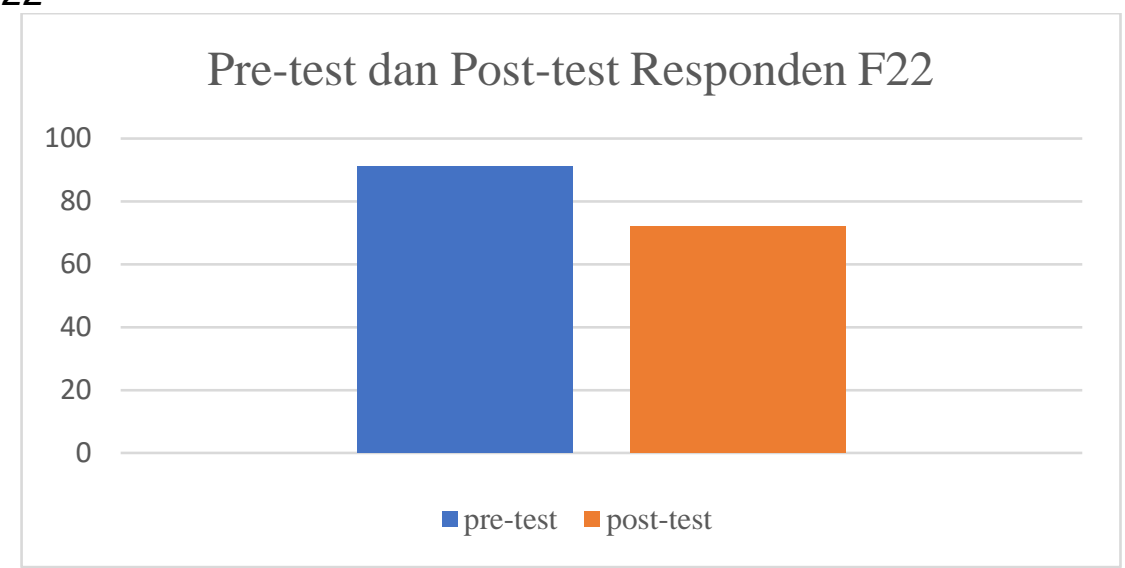

Gambar 4. Hasil dari Pre-test dan Post-test Responden F22

Skor tinggi kejenuhan belajar yang dicapai oleh responden F22 meningkat. Kondisi kejenuhan belajar yang dialami oleh responden F22 dalam taraf tinggi. Sebelum mendapatkan treatment kejenuhan belajar yang dicapai adalah sebesar 91, dan setelah mendapatkan treatment maka skor kejenuhan pada responden F22 sebesar 72 dengan kriteria kejenuhan pada taraf sedang. Sebelum melakukan treatment, responden F22 merasakan resah dalam belajarnya karena setiap belajar dirumah selalu diganggu oleh adiknya dan meteri yang diberikan oleh gurunya sulit untuk dipahami sehingga membuatnya jenuh. Tetapi setelah mendapatkan treatment responden F22 merasa lebih tenang menghadapi materi yang sulit dan lebih semangat untuk belajar.

\section{Responden F23}

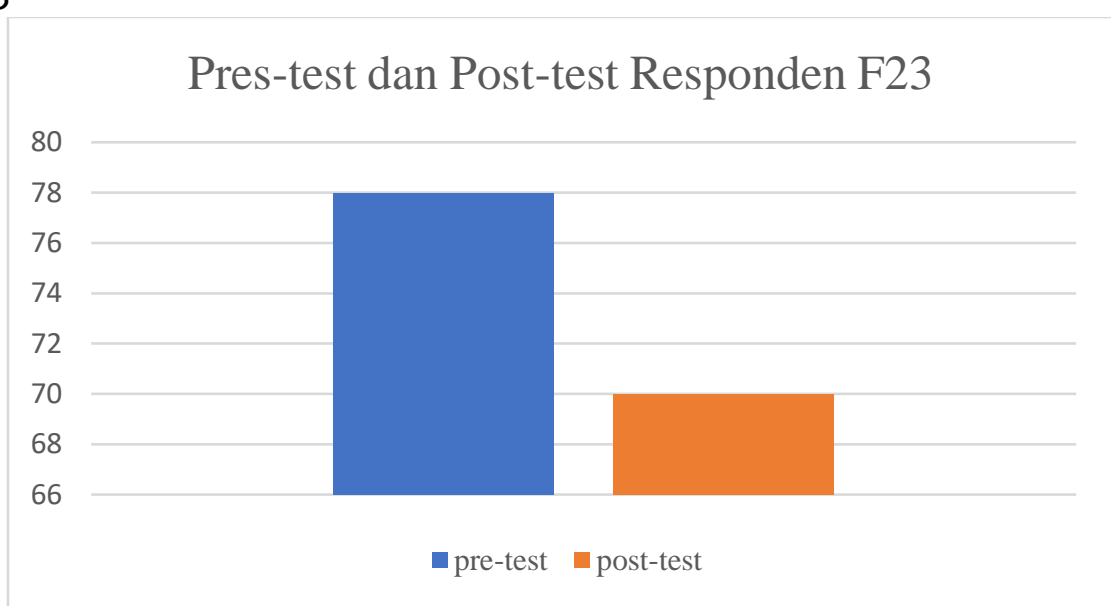

Gambar 5. Hasil dari Pre-test dan Post-test Responden F23

Skor tinggi kejenuhan belajar yang dicapai oleh responden F23 meningkat. Kondisi kejenuhan belajar yang dialami oleh responden F23 dalam kategori tinggi. Sebelum mendapatkan treatment, skor kejenuhan belajar yang dicapai sebesar 78 , dan setelah mendapatkan treatment, skor kejenuhan belajar yang dicapai menurun sebesar 70 dengan kategori rendah. Sebelum dilakukan treatment, individu mengalami jenuh akibat materi yang didapat dari guru disekolah selama pembelajaran online sulit dipahami. Namun setelah mendapatkan treatment individu sudah tidak jenuh lagi dan belajarnya juga sudah mulai lebih semangat. 
84 Traditional play therapy "Bancakan" efektif dalam mengurangi kejenuhan pembelajaran daring siswa SMA saat pandemi Covid-19

\section{Responden F25}

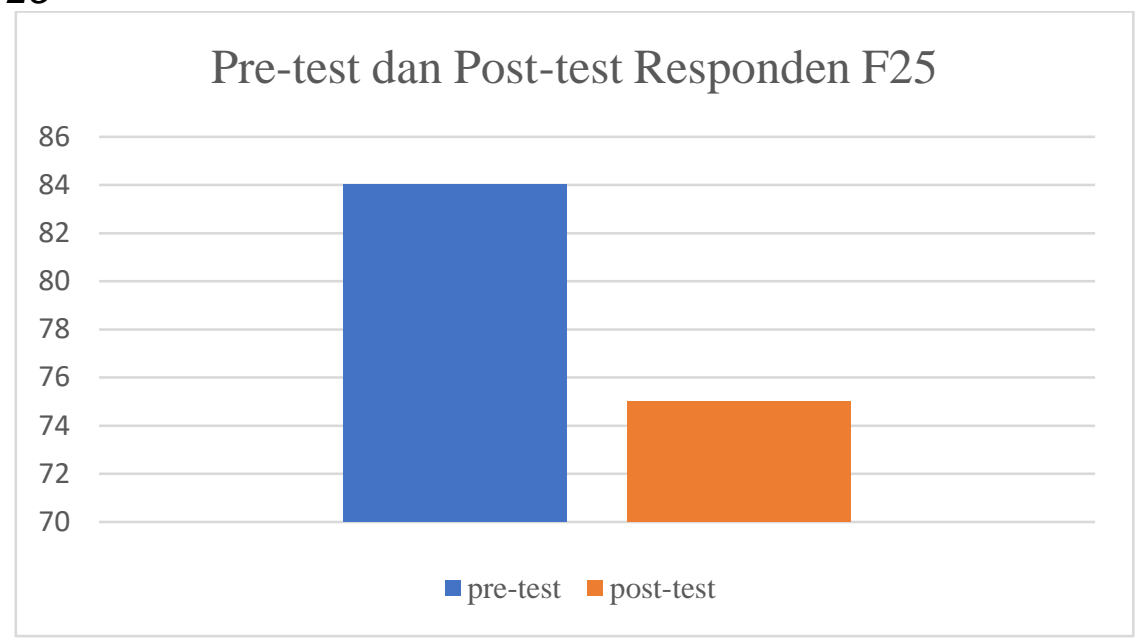

Gambar 6. Hasil dari Pre-test dan Post-test Responden F23

Skor tinggi kejenuhan belajar yang dicapai oleh responden F25 meningkat. Kondisi kejenuhan belajar yang dicapai sebelum mendapatkan treatment sebesar 84, dan setelah mendapatkan treatment maka skor yang didapat oleh responden F25 menurun sebesar 75. Sebelum dilakukan treatment individu tidak mau belajar karena materi yang didapat sangat sulit dipahami sehingga membuatnya jenuh dalam belajarnya. Tetapi setelah mendapatkan treatment indivividu sudah mulai semangat lagi untuk belajar dan apabila ada materi yang tidak dipahami individu tersebut mengajak temannya untuk belajar bersama sehingga materi yang tidak dipahami bisa bertanya sama teman kelasnya.

\section{Responden F26}

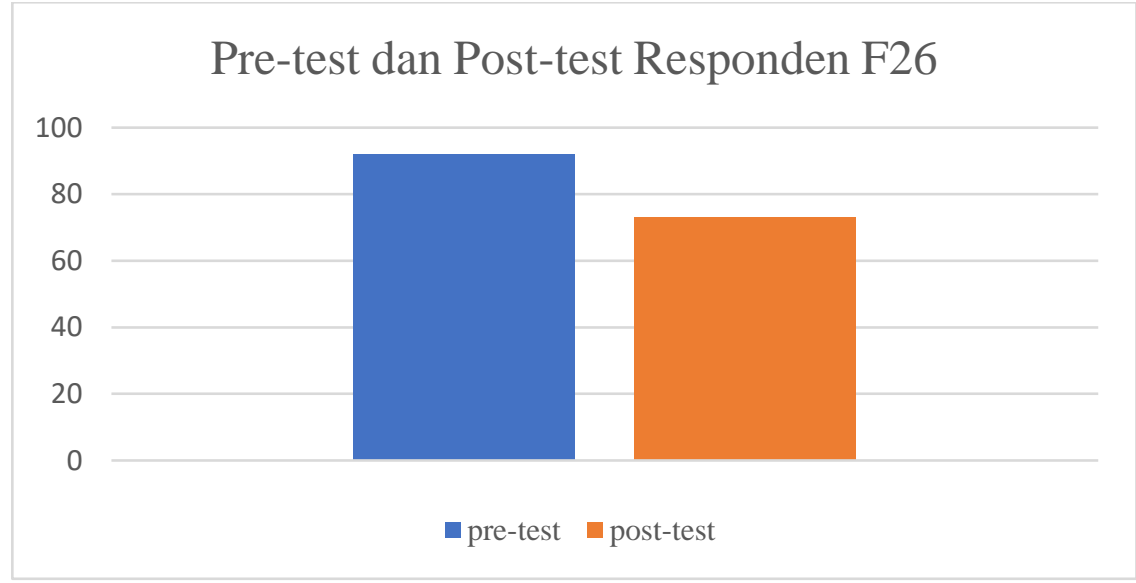

Gambar 7. Hasil dari Pre-test dan Post-test Responden F26

Hasil pre-test responden F26 meningkat, dalam kategori kejenuhan belajar siswa tinggi. Sebelum mendapatkan treatment kejenuhan belajar yang dialami oleh responden F26 mencapai sebesar 92, dan setelah mendapatkan treatment maka skor yang didapat menurun sebesar 73 dalam kategori rendah. Sebelum dilakukan treatment individu terjadinya kesulitan terhadap pengerjaan tugas yang disampaikan guru yang ada di sekolah. Akan tetapi, sesudah dilakukan treatment individu tersebut sudah mulai bisa mengerjakan tugas-tugasnya dengan bekerja sama dengan teman sekelasnya. 


\section{Responden F30}

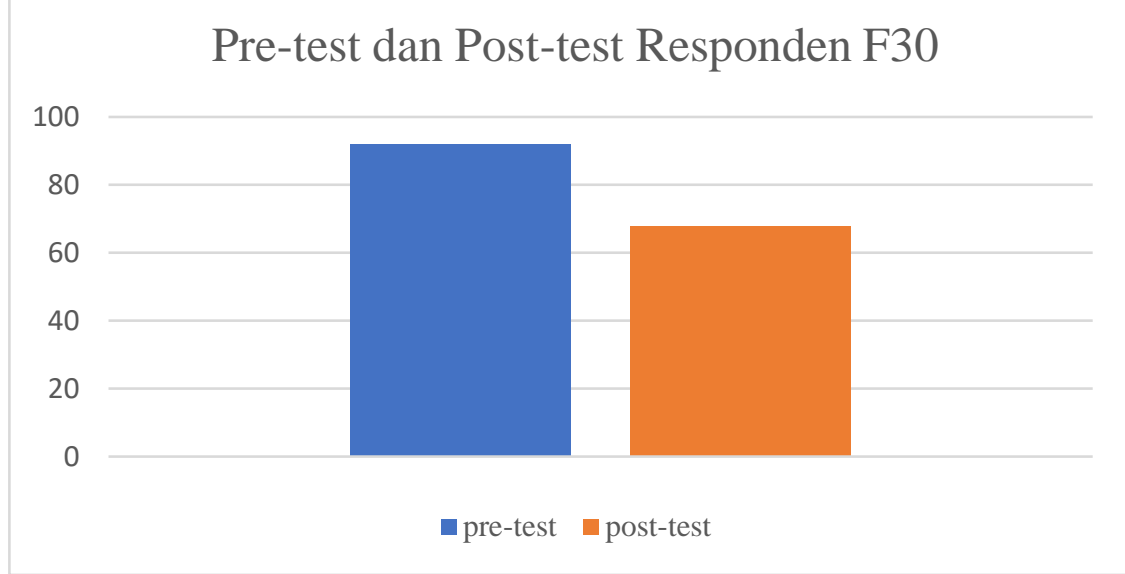

Gambar 8. Hasil dari Pre-test dan Post-test Responden F23

Skor tinggi kejenuhan belajar yang dicapai oleh responden F30 meningkat. Kondisi kejenuhan yang dialami oleh responden tersebut dalam kategori tinggi. Sebelum mendapatkan treatment kejenuhan belajar yang dicapai sebesar 92, dan setelah mendapatkan treatment maka skor kejenuhan belajar pada responden F30 menurun sebesar 68 dengan kategori rendah. Sebelum dilakukan treatment, individu mengalami jenuh dalam belajarnya karena banyak tugas yang diterima dari sekolah dan individu tersebut tidak berani untuk bekerja sama mengerjakan tuganya dengan teman kelasnya. Tetapi setelah dilakukan treatment individu sudah mulai merasakan tidak jenuh dan sudah mulai memberanikan diri untuk bekerja sama mengerjakan tugas sekolahnya dengan teman-temannya.

Dari uraian di atas dapat disimpulkan bahwa dari ke-8 responden tersebut mengalami penurunan kejenuhan belajar siswa dengan teknik permainan tradisional bancakan dalam bimbingan kelompok. Hal ini semakin memperkuat bahwa manfaat play therapy sangat banyak, tidak hanya untuk masalah sosial (Bilqis, 2017; Bilqis et al., 2017; Saripah \& Bilqis, 2019; Bilqis, 2021), tetapi juga dapat untuk mengatasi masalah belajar. Play therapy membantu memperkuat persepsi positif siswa. Seperti yang disebutkan oleh Bilqis (2013), persepsi mempengaruhi perilaku seseorang. Konselor memiliki peran yang sangat penting dalam hal ini (Bilqis et al., 2019).

\section{Simpulan}

Dari hasil penelitian, diperoleh hasil bahwa terjadi peningkatan nilai rata-rata (mean) skor variabel kejenuhan belajar pada $\mathrm{N}=8$. Nilai mean yang dihasilkan saat sebelum adanya layanan bimbingan kelompok sebesar $92 \%$. Sedangkan, hasil pada saat setelah adanya layanan bimbingan kelompok nilai mean turun menjadi $62 \%$. Hasil hipotesis menggunakan uji Wilcoxon diketahui bahwa Asymp. Sig. =0,012 perbandingan Asymp. Sig. $=0.012<\alpha=0,05$ maka dinyatakan Ho ditolak dan Ha diterima dengan artian terdapat pengaruh pada penggunaan play therapy dengan permainan tradisional bancakan dalam bimbingan kelompok terhadap kejenuhan belajar siswa.

\section{Daftar Rujukan}

Bilqis, F. (2013). Hubungan Antara Persepsi Dengan Cara Penyelesaian Konflik Interpersonal Pada Siswa Kelas XI Jurusan Akuntansi SMK Mahardhika. Jurnal BK UNESA, 3(1).

Bilqis, F. (2017). PERBEDAAN KEEFEKTIFAN ANTARA ADLERIAN GROUP PLAY COUNSELING DAN LAYANAN BIMBINGAN KLASIKAL DALAM MENINGKATKAN DAYA TARIK INTERPERSONAL: Penelitian Mix-Method terhadap Siswa Kelas $V$ SDN 
86 Traditional play therapy "Bancakan" efektif dalam mengurangi kejenuhan pembelajaran daring siswa SMA saat pandemi Covid-19

Sukasenang dan SDN Cihaurgeulis 2 Tahun Ajaran 2016/2017. Universitas Pendidikan Indonesia.

Bilqis, F. (2021). Does Adlerian Play Therapy Increase Social, Physical, and Task Appeal More Than Content Mastery Services in Elementary School Students? Child Education Journal, 3(1), 1-18.

Bilqis, F., Karina, T., \& Latipah, I. C. (2019). Peran konselor dalam mewujudkan sekolah aman dan damai bagi siswa. TERAPUTIK: Jurnal Bimbingan Dan Konseling, 2(3), 115-122.

Bilqis, F., Taufiq, A., \& Saripah, I. (2017). The Effectiveness Differences Of Adlerian Group Play Counseling And Classroom Guidance Activity In Improving Interpersonal Attractiveness. Psikopedagogia Jurnal Bimbingan Dan Konseling, 6(2), 12-19.

Dewi, R. P., Yosef, \& Harlina. (2017). Hubungan antara Academic Self-Confidence dengan Kejenuhan (Burnout) Belajar Siswa SMK Negeri 1 Indralaya Utara. Konseling Komprehensif, 4(2), 14-27.

Guidelines, G. E., Xi, C., Students, I. P. S., Negeri, S. M. A., Hasliah, P., Penelitian, A., Ips, X. I., Negeri, S. M. A., \& Ips, X. I. (2020). BIMBINGAN KELOMPOK TEKNIK GAMES PADA SISWA KELAS XI IPS SMA NEGERI 1 PAREPARE. IX, 125-155.

Laili Sulistyowati, A. N. (2015). Layanan Bimbingan Kelompok Untuk Meningkatka Keterampilan Belajar Siswa. Edukasia: Jurnal Penelitian Pendidikan Islam, 10(2), 413-430. https://doi.org/10.21043/edukasia.v10i2.801

Nawangsih, E. (2016). Play Therapy Untuk anak-anak Korban Bencana Alam Yang Mengalami Trauma (Post Traumatic Stress Disorder/PTSD). Psympathic : Jurnal Ilmiah Psikologi, 1(2), 164-178. https://doi.org/10.15575/psy.v1i2.475

Pawicara, R., \& Conilie, M. (2020). Analisis Pembelajaran Daring Terhadap Kejenuhan Belajar Mahasiswa Tadris Biologi lain Jember di Tengah Pandemi Covid-19. ALVEOLI: Jurnal Pendidikan Biologi, 1(1), 29-38.

Sari, P., Kholidin, F. I., \& Edmawati, M. D. (2019). Tingkat Kejenuhan Belajar Siswa Sekolah Menengah Pertama Di Kota Bandar Lampung. Journal of Chemical Information and Modeling, 1(1), 45-52.

Saripah, I., \& Bilqis, F. (2019). Pengembangan program Adlerian group play counseling untuk meningkatkan daya tarik interpersonal siswa kelas V Sekolah Dasar. TERAPUTIK: Jurnal Bimbingan Dan Konseling, 2(3), 141-155.

Susilo, A., Rumende, C. M., Pitoyo, C. W., Santoso, W. D., Yulianti, M., Herikurniawan, H., Sinto, R., Singh, G., Nainggolan, L., Nelwan, E. J., Chen, L. K., Widhani, A., Wijaya, E., Wicaksana, B., Maksum, M., Annisa, F., Jasirwan, C. O. M., \& Yunihastuti, E. (2020). Coronavirus Disease 2019: Tinjauan Literatur Terkini. Jurnal Penyakit Dalam Indonesia, 7(1), 45. https://doi.org/10.7454/jpdi.v7i1.415

\section{Competing interests:}

The authors declare that they have no significant competing financial, professional or personal interests that might have influenced the performance or presentation of the work described in this manuscript. 